\title{
Theory Travel: Translation of Western Contemporary Literary Theories to China
}

\author{
Lu Jie 1,2 $^{1,2}$ \\ ${ }^{1}$ Foreign Language College, Chengdu University of Information Technology, China \\ ${ }^{2}$ College of Literature and Journalism, Sichuan University, China
}

Copyright $\mathrm{O} 2017$ by authors, all rights reserved. Authors agree that this article remains permanently open access under the terms of the Creative Commons Attribution License 4.0 International License

\begin{abstract}
From the beginning of the 20th century, many Western contemporary literary theories, including formalism, the New Criticism, phenomenology, hermeneutics, reception aesthetics, structuralism, deconstruction, psychoanalysis, post-colonialism and Western Marxism, have been translated into Chinese. Translation of those Western literary theories has undergone four phases in China over a century's travel: the commencement and development from the early 1920s to the late 1940s, the frustration and depression from the late 1940 s to the end of 1970 s, the recovery and revival from the late 1970 s to the late 1990 s as well as the sustained development and new turn from the beginning of the 21st Century till now. Translation of Western contemporary literary theories is an indispensable part in modern "eastward transmission of Western learning," therefore, to retrospect and summarize its procedure in China is not only helpful to recognize the value and significance of Western contemporary literary theories in Sino-Western cultural exchanges but also beneficial to rationally reconsider the ways to construct Chinese contemporary literary theories in a new era.
\end{abstract}

Keywords Theory Travel, Western Contemporary Literary Theories, Translation, Sino-Western Cultural Exchanges

\section{Introduction}

An academic symposium called "Thirty-year Development of China's Comparative Literature and New Pattern of International Comparative Literature" was held in Shenzhen University on December 26, 2015. Cao Shunqing, president of Chinese Society of Comparative Literature and "Yangtze River Scholar" Chair Professor of China's Ministry of Education, delivered a speech entitled "Comparative Poetics is setting up New Patterns" in the opening ceremony. Professor Cao pointed out that the previous paralleled analogical researching paradigm caused the problem of "over-simplified comparison" and deficiency of "mode of seeking commonness", and the key to solving the problem and make up for it is to "explore a way of influential study in comparative poetics" from perspectives of clarifying Chinese elements in Western theories and noticing variations in theory travel. The research on translation of Western contemporary theories is inseparable and significant for the study of "variations in theory travel." Through the research on China's translation and introduction of Western contemporary theories, the essay tries to probe and discover some factors that manipulate Chinese scholars' translation behaviors and rationally reconsider the construction of China's contemporary literary theory system. Retrospection of China's translation of Western contemporary theories in the four phases(the commencement and development from the early 1920s to the late 1940s, the frustration and depression from the late 1940s to the end of 1970 s, the recovery and revival from the late 1970s to the end of the $20^{\text {th }}$ century as well as the sustained development and new turn from the beginning the $21^{\text {st }}$ century till now) contributes to cast light on some hidden powers which decided or influenced these theories' travel experiences in China.

\section{Commencement and Development: from the Early 1920s to the Late 1940s}

China's early translation of Western contemporary literary theories began in the early 1920 s, reached its first summit at the middle of 1930s and declined in the 1940s. It had experienced approximately ten years' prosperity in the first phase. According to the statistics given by Chinese National Library, Shanghai library and Zhongshan Library, 27 kinds of works on literary theories had been translated into Chinese from 1920 to 1937(the year of "national calamity" caused by Japan's aggression) and 7 kinds had been translated from 1937 to 1947 , excluding some translated essays published by 
magazines and initial editions about literary criticism, literary thoughts and literary history. The translation of Western contemporary literary theories in China at that time was featured with broad horizons, open-mindedness and synchronization with the development of Western literary criticism abroad. In the first translation wave, translation of the New Criticism outnumbered and dwarfed that of other Western contemporary literary theories. Translation of psychoanalysis ranked the second place in number and also had great influence on China. Translation of formalism, phenomenology, structuralism, deconstruction, and Western Marxism was not only smaller in proportion but also lagged far behind their domestic development, so they had relatively less impact on China compared with translation the of the New Criticism and psychoanalysis.

\subsection{Translation of Psychoanalysis Marked the Beginning of China's Translation of Western Contemporary Literary Theories}

China's translation of psychoanalysis can be traced back to early 1920s. "On Psychoanalysis" by Zhang Dongsun was published in the magazine "Min Duo" in 1920 and was reprinted by a newspaper "Shishi Xinbao XXuedeng (Current Affairs Weekly' Lamp of Learning)" on the $12^{\text {th }}$ of May, next year. In December of 1922, a long essay named "Psychoanalysis and Literature", which is a translation of a Japanese scholar Matsumura Takeo's works by Zhong Yun was published in "Wenxue Zhoubao (Literature Weekly)" No.57. As China's earliest systematical and explicit explanation and introduction to literary and artistic thoughts contained in psychoanalysis, the essay analyzed various symbolical meanings carried by sexual lust with abundance of arguments and convincing argumentations. Two years later, Lu Xun translated Kuriyagawahakuso's "The Symbol of Depression", which exerted great influence on Chinese modern psychoanalytical criticism. Concurrently, Freud's speech "The Origin and Development of Psychoanalysis" was translated by Harry W. Chase and published in "Jiaoyu Zazhi (Journal of Education)" by the Commercial Press. All the translation mentioned above paved the way for China's fuller acceptation and absorption of psychoanalytical theory in the next decade.

From the 1930s to 1940s, China's translation of psychoanalysis developed naturally and smoothly. Sigmund Freud's theories were translated by Gao Juefu into two collections and published by the Commercial Press respectively in 1933 and 1935. Gao's translated collections of "Introductory Lectures on Psycho-Analysis" and "A New Introduction to Psycho-Analysis" provided Chinese intellectuals with precious information about Freud's psychoanalytical theories. In 1940, Dong Siqiu translated R.Osbourne's "Freud and Marx". He analyzed and wrote about Freud's contribution and limitation in the preamble: "Psychoanalysis is of partiality and aberration as many other sciences are, and its biggest flaw is that it belongs to the realm of metaphysics." [1]In short, psychoanalysis is the earliest Western contemporary literary theory translated into China. Despite its limited range and scale, the translation and introduction to it literally marked the beginning of China's translation of Western contemporary literary theories.

\subsection{Translation of the New Criticism is the Biggest Accomplishment in China's Translation of Western Contemporary Literary Theories}

China's translate on of the New Criticism can be dated back to 1927 when Zhu Ziqing translated Raymond D. Jameson's "Pure Poetry" and published it in "Xiaoshuo Yuebao (Novel Monthly)" (Vol.18, No.20). At publication of Zhu's translation, the term "pure poetry" immediately began popular in Chinese critic circle. Two years later, I.A. Richards' work "Science and Poetry" was translated by a translator with a pseudonym Yiren and published by Huayan Publishing House. In 1933, a series of European modern literary theories, including "Tradition and the Individual Talent" by Eliot, was translated by Cao Baohua and published in "Beiping Chenbao-Xue Yuan (Beiping Morning 'Garden of Learning)." The next year, the essay was again translated by Bian Zhilin for the purpose of the initial issue of "Xuewen Yuebao (Learning Literature Monthly)." Bian's translation was quoted more frequently than that of Cao, and it had greater influence on China's literature creation and criticism, so it was regarded as the hallmark of New Criticism's official landing in mainland China. From the materials mentioned above, it can be summarized that China's translation of the New Criticism began from late 1920s when Chinese scholars' interest mainly lay on Eliot and Richard's works and translation of the New Criticism was featured with synchronization with its domestic development.

From the middle of the 1930 s to the 1940s, China's translation of the New Criticism thrived: The first chapter of "The Principles of Literary Criticism" was translated by Shi Honggao and published in "Wenxue Jikan (Literature Quarterly)" in September of 1935 under the title of "Divergences in Critical Theories." In October of 1935, the prelude to "The Use of Poetry and Use of Criticism" was translated by Zhou Liangxi and published in the first volume of "Xiandai Shifeng (Modern Poetic Style)" edited by Dai Wangshu. In February of 1936, Tu Xuxuan's translation of "On Poetry's Experience", the second chapter of "Science and Poetry", was published in "Wenyi Yuekan (Literature and Art Monthly)." In October of 1936, "Shida Yuebao (Monthly Journal of Normal University)" (Vol.30) published Zhao Zenghou's translation of Eliot's "The Use of Poetry and Use of Criticism—-Modern People's Conception." In 1937, the whole book "Science and Poetry" was translated by Cao Baohua and published by the Commercial Press. Among the multitude of translation, it was "Modern Poetics" translated and edited by Cao Baohua that had the greatest impact on China and was universally acknowledged as the 
most important translated collection of the New Criticism in that period. Cao Baohua had translated maximum of works about the New Criticism in the first half of the $20^{\text {th }}$ century. Besides books like "Science and Poetry" and "Tradition and the Individual Talent," he also translated some influential essays, such as "Function of Criticism" and "Experiment in Criticism" by Eliot as well as "On Poetry's Experience", "The Four Kinds of Meaning" and "Practical Criticism" by Richards which were all collected in "Modern Poetics" and published by the Commercial Press in 1937.

On the one hand, America witnessed the prime time of the New Criticism in the 1940s; on the other hand, some Western luminaries' participation in China's academic activities pushed the dissemination of this theory in China, China's translation of the New Criticism consequently gained further development in this decade. For example, Yuan Kejia combined creation of Chinese modern poetry in the 1940s with Richards' definition of poetry from perspective of psychological poetics and aimed at the ideology that literature should submit to politics which was put forward by realist poetics in China at that time, and he proposed that poetry should "be guided by the principle of "serving the people",, "stick to the stances of human and life", "without prejudice to politics", "stick to the standpoints of literature and art". [2]Yuan Kejia initiated the sinolization of New Criticism by the combination of the New Criticism's artistic ontology and China's political reality. Generally speaking, translation of the New Criticism is the biggest accomplishment in China's early translation of Western contemporary literary theories, no matter being measured by promptness, influence, or the quantity and quality of translated works.

\subsection{Translation of Other Western Contemporary Literary Theories Embodies China's Open-mindedness in Academic Research in the First Phase}

Although China's translation of phenomenology, formalism, structuralism, and Western Marxism was quite limited and lagged far behind their domestic birth and development, those fragmentary and unsystematic translated works were indispensable parts for the integration of China's early translation of Western contemporary literary theories and embodied China's willingness to absorb heterogeneous thoughts with open and broad mind.

\subsubsection{Translation of Phenomenology}

China's translating of phenomenology began in the 1920s. Although when Fan Bingqing explained the item of "phenomenology" in "Dictionary of Philosophy" published by the Commercial Press in 1926, he still referred to Hegel and Kant's "phenomenology" in philosophical meaning instead of Husserl's "phenomenology" in literary criticism, his explanation was the earliest extant record on "phenomenology" can be found in China. In March of 1928,
"Modern Philosophy", an essay by Japanese existentialist Nishida Kitaro was translated by Liu Chongjin and published in a magazine named "Min Di" (Vol.9, No.3). Later, another essay named "General Introduction to Phenomenology" edited by Yang Rengeng was published on "Min Duo" (Vol.10, No.1) next year. [3]The publication of these two essays marked the commencement of China's translation of Husserl's phenomenology. But afterwards China's translation of Husserl's phenomenology had endured about 50 years of silence from the 1930 s to 1978 (the year of China's opening and reform), with "Existentialist Philosophy" edited by panel of Western philosophy history in Institute of Philosophy of Chinese Academy of Sciences and issued as "internal reading material" by the Commercial Press the only outstanding relevant translated material. The book included Xiong Wei's selected translation of the foreword and some chapters in "Bing and Time" and Heidegger's letter "On Humanism." [4]Therefore, China's translation of phenomenology is as temporary as a flash compared with its translation of other Western contemporary literary theories at that time. Heidegger once commented phenomenology in his memoir: "Phenomenology.....in various field, mainly exerting influence unconsciously, determines the spirit of the time." [5]Some scholars believe it is phenomenology's property of "unspeakablity" that partly caused China's indifference to it. Some other scholars believe that the coincidences between phenomenology and China's traditional philosophy illustrated by Laozi and Zhuangzi reduced the attraction of phenomenology when China longed for learning some more "advanced" ideas from the West at that time, so although phenomenology was one of the significant Western contemporary literary theories, it lost the charm of heterogeneity to China because it was not very typically Western in Chinese scholars' eye then.

\subsubsection{Translation of Formalism}

Formalism is the earliest Western literary theory born in the $20^{\text {th }}$ century. It was prevalent in Russia from 1915 to 1930. China's earliest translation of formalism began with an essay named "Debate on Formalism in Literature and Art of the Soviet Union" which was published on "Zhongsu Wenhua (Chinese and Russian Culture)" (Vol.1, No.6). But because formalism overstressed the independence of aestheticism and the absolute of artistic form, it was suppressed by Stalinism in the middle of the 1930s and its development was almost completely halted in the Soviet Union. Its adverse situation at home directly influenced its translation and dissemination in China: just like phenomenology, translation of formalism was also quite limited and transient in China at that time.

\subsubsection{Translation of Structuralism}

China's translation of structuralism began in the 1930s when P.E.Passy's "Comparative Phonetics" was translated by Liu Fu. Two years later, Dajiang Shupu Pressing House published Chen Wangdao's book “An Introduction to 
Rhetoric" which introduced some key concepts proposed by Saussure. In 1939, "General Introduction to Phonetics" edited by Cen Qixiang introduced some works on phonetics written by English, French and Japanese scholars and elaborated some definitions in structuralism, such as "phonology" and "phoneme". Since levi- Strauss' structuralism in terms of cultural anthropology didn't come into being in West at that time yet, it followed that China's translation of structuralism was also confined in linguistic domain. In this period, no real structuralism in terms of literary theory was translated into China.

\subsubsection{Translation of Western Marxism}

China's translation of Western Marxism began in the 1930s. Along with the swarm of Western ideological trend, many books written by Georg Luacs, the founder of Western Marxism, were translated into China. "Zola and Realism" published on "Yiwen (Rendition)" (Vol.2, No.2) in 1935 is the first translation and introduction to Lucacs' aestheticism. Later "The Essence of Novel", the first section of "Novel Theory" by Lucacs was translated by Hu Feng and published in "Xiao Shuo Jia (Novelist)" in 1936. Four years Later, "On Realism" translated by Wang Chunjiang was published in "Wenxue Yuebao (Literature Monthly)" and "Narration and Depiction" translated by Lü Ying was published consecutively in the first and second issue of the "Qi Yue (July)" (Vol.6). Therefore, it can be safely concluded that Lucacs' thought and ideology did have no small impact on China in the first phase of China's translation of Western contemporary literary theories.

In conclusion, in the first phase of China's translation of Western contemporary literary theories, China's preference and selection in its translation was boosted and refrained by a diversity of factors. Firstly, the commencement of China's translation of Western contemporary literary theories just followed the "May Fourth Movement", when domestic academic circle esteemed Western literary theories as alias for "new" and "advanced" thoughts, so psychoanalysis, the New Criticism, phenomenology, formalism, structuralism and Western Marxism just satisfied Chinese scholars' desire to catch up with new currents in world literature. Secondly, Western scholars, such as I. A. Richards, William Empson, and Raymond D. Jameson together with Chinese scholars, such as Zhu Ziqing, Ye Gongchao, Cao Baohua, Li Anzhai and Qian Zhongshu, communicated and exchanged ideas frequently, which greatly pushed China's translation of some Western contemporary literary theories. This dynamic force was especially conspicuous in China's translation of the New Criticism. Zhao Yiheng once said: "Some big men in the New Criticism had close relation with China's modern Academy. For example, Richards had been to China for 6 times until he fell down in China's classroom; Empson collaborated with Chinese teachers and students in Southwest Associated University in the anti-Japan war and welcomed China's liberation in Peking University. Their activities had all been mentioned as interesting and encouraging anecdotes in China's academic history." [6]At last, China's translation of Western contemporary literary theories was also determined by the whole nation's situation, especially political situation and macro-environment for translation. Liao Qiyi once collected some statistics and concluded: "1935 is a harvest year for China's translation. China's translation of English and American literature boomed around this year. From 1933 to 1937, as many as 307 pieces of English and American literature works had been translated into China. While from 1938 to 1942, only 150 pieces had been translated. Then from 1946 to 1948, over 100 pieces had been translated every year." [7]These figures proved that China's macro-environment influenced the development of China's translation of Western contemporary literary theories. Especially the big calamity and chaos caused by Japan's aggression hindered China's previous smooth development of translation of Western contemporary literary theories and made it difficult to form a system and doomed to decline from 1938 to 1942.

\section{Frustration and Depression: from the Late 1940s to the Late 1970s}

After the foundation of People's Republic of China, China followed the suite of artistic policy pursued by the Soviet Union, so Western contemporary literary theories were reckoned as ideology that went against domestic mainstream of socialist ideology and were banned and oppressed officially. In the ten years of "the Great Cultural Revolution", the ideological confrontation and contention between socialist China and capitalist Western countries grew fiercer and fiercer, so Western contemporary literary theories, being equaled to "decadent capitalist thoughts", suffered unprecedented denunciation. The translation of Western contemporary literary theories met a serious stagnation from 1949 (the foundation of the PRC) to 1978 (China's opening and reform). Some Chinese scholars pointed out that after the 1950s Chinese literary theory gradually took on a look of "respecting exclusively Marxism and abandoning all the other critical theories" and "this process made literary criticism theories sheer utilized devices for policy and politics." [8]It was the permeation and pressure from external factor like political ideology that brought about such depressing situation in China.

\subsection{Translation of Most Western Contemporary Literary Theories Fell in "Stagnation"}

From the late 1940 s to the late 1970 s, formalism, phenomenology and psychoanalysis which had been unsystematically translated into Chinese in the previous phase were halted because of their deviation from the ideological mainstream in China. Deconstruction, hermeneutics, reception aestheticism and post-colonialism which were born in the 1960s and the 1970s were rejected 
and repelled out of China because of the seclusion in "the Great Cultural Revolution"(1966-1976). When those Western contemporary literary theories raised big waves in Europe and America, mainland China was in the sharpest confrontation with Western thoughts and theories. Political ideology had the biggest influence on China's translation and reception of Western contemporary theories. In the second phase, almost no books on Western contemporary literary theories had been published publicly, and translation of most Western contemporary literary theories fell into "stagnation".

\subsection{Translation of a Small Portion of Western Contemporary Literary Theories Continued out of the Necessity of "Denunciation"}

Despite it was in the period of most serious frustration and toughest time for translation of Western contemporary literary theories, translation of the New Criticism, Western Marxism and structuralism still continued, because China couldn't turn a blind eye to these three theories since the New Criticism had already gained great attention in the previous phase, Western Marxism was being criticized in almost every socialist country and structuralism was influential in the Soviet Union. Primarily out of the necessity of "denunciation", the translation of these three theories continued in the special period. However, amid the extremely left political air during "the Great Cultural Revolution" when it was universally believed in China that "nothing in capitalist countries is advanced; nothing in socialist countries is corrupted," [9] these Western contemporary literary theories were translated as negative examples and issued in limited circles for some superiors who were believed to harbor firm belief in socialism and would not be corrupted by these Western thoughts.

\subsubsection{Translation of the New Criticism}

In the 1950s, because China advocated Marxist artistic theory which valued practical functions of literature and ignored the ontology of literature itself, and the New Criticism went against the main current of China's literary theory, the translation of New Criticism fell into obscurity. In the 1960s, along with Chinese political environment's tight curb on literature and art, the New Criticism became the target of attack and criticism. In 1962, Yuan Kejia took the lead in denouncing Elliot. He said: "(Elliot) is a head of a very rampant monopolistic group in capitalist British and American reactionary and decadent literature and an authorized scholar who was devoted to British and American imperialism."[10] However, after his severe denunciation, he continued to make a thorough exploration on the New Criticism in the essay. Generally speaking, his research on the New Criticism's origins, some theories proposed by Elliot and Richards, as well as organic formalism and semantic analysis presented in this essay were very valuable, so it is admitted by many Chinese scholars that Yuan's research under disguise of "denunciation" ensured him to be an uncontroversial frontier in history of the translation of the New Criticism. In the same year, some masterpieces in the New Criticism were included into a collection named "Contemporary Capitalist Theories on Literature and Art in Britain and America" and published by the Writers Press. Bian Zhilin's translation of Elliott's "Tradition and the Individual Talent", Yang Zhouhan's translation of Richards' "Principles of Literary Criticism", Zhang Guruo's translation of Ransom's "Criticism as Pure Speculation", Mai Renzeng's translation of Empson's "Seven Types of Ambiguity" and Yuan Kejia's translation of Brooks' "Irony as a principle of structure" included in this collection had been the only Chinese materials on the New Criticism available in China. "Xiandai Waiguo Zhexue Shehui Kexue Wenzhai (Contemporary Foreign Philosophical and Social Science Digest)" also published some translated essays on the New Criticism in that period. For example, René Wellek's "The Main Trends of Twentieth-Century Criticism" (trans. Jiang Kongyang) was published in it in 1962; Wellek's "Principles of Literary Criticism" (trans. Shi Fu) was published in it in 1964. But Shi Fu said before his translation: "Wellek advocates 'humanity' to be taken as essence of literature. He encourages so-called 'internal study' which studies literature exclusively from literary angles and denies literature's close relation with society, politics and economy. He denies the basic literary principle that literature is the reflection of social reality, hence human will naturally be an abstract conception deprived of class attribute." [11]Yuan's words are the earliest comments on Welleck's masterpiece "Theory of Literature" in China. From the translated works mentioned above, it can be easily seen that the aim of translating the New Criticism was mainly for "denunciation" and most translated works on it can be published in this period were under the disguise of "criticizing capitalist corrupted thoughts".

\subsubsection{Translation of the Western Marxism}

Influenced by the "ultra-leftist" ideology at home, Chinese accepted the idea that dogmatic Marxist theories are the orthodox of Marxism and Western Marxism is not Marxism at all. The slogan "socialist grass is preferable than capitalist seedling" vivified Western Marxism's hard and embarrassed situation in China at that time. In the anti-revisionism campaign in the 1950s and 1960s, Lucacs was denounced as the representative of international revisionism, which made institute of philosophy of Chinese Academy of Sciences organize some elites to translate three influential philosophical books written by Lucacs, including "Existentialism and Marxism?" (trans. Han Runtang, the Commercial Press, 1962), "The Young Hegel (excerpted)" (trans. Wang Jiuxing, the Commercial Press, 1963) and "The Destruction of Rationality" (the translation of the book had been accomplished before the selected translation of "The Young Hegel", but the draft was lost in "the Great Cultural Revolution", so it was retranslated by Wang Jiuxing in the 
1980s and finally published by Shandong People's Publishing House in 1988.) Western Marxism, as a theory that suffered the severest denunciation, was paradoxically translated most systematically out of the necessity of "denunciation".

\subsubsection{Translation of Structuralism}

Liu Yongquan's translation of "Some Suggestions on Structuralism" by Михаил Иванович Стеблин-Каменский, a scholar from the Soviet Union was published in "Zhongguo Yuwen (Studies of The Chinese Language)" 1957(8). In the same year, "Ewen Jiaoxue (Russian Language Education)" published "Structuralism and its Methodology" and serialized "Sketch of European Linguistics: from the $19^{\text {th }}$ Century to the $20^{\text {th }}$ Century" written by Дегтерева, Т. A. In 1958, "Structuralism in Linguistics and its Primary Schools", the eleventh chapter of "Introduction to History of linguistics" by Chen Qixiang, introduced Saussure's theory about structuralist linguistics and its consecutive three schools, including Prague school, Copenhagen school and American descriptive school. In short, the introduction and discussion on structuralism was greatly influenced by the linguistics research in the Soviet Union and mainly concentrated on linguistic level.

It was in the middle of the 1970s when structuralism declined in Western countries due to the impact from "post-structuralism" that structuralist literary criticism was formally introduced into China. Some Taiwan scholars, such as Zhang Hanliang, Zheng Shusen and Zhou Yingxiong, were the earliest critics who employed structuralist literary theory to criticize Chinese literature. Whereas translation of structuralist literary theory in mainland China began in 1975 when "Recent European Ideological Trend of Structuralism" was published in "Zhexue Shehui Kexue Dongtai (Philosophical and Social Science Development)" in 1975(4). This essay denounced structuralism as the ultimate embodiment for the collapse of Western capitalist philosophical and social ideologies. In 1978, several essays explaining structuralist literary theory had been published in "Zhexue Yicong (Translated Serials on Philosophy)", but none of them attracted ample attention from Chinese academia, which proved that structuralism's unpopularity in China at that time.

Generally speaking, China's translation of Western contemporary literary theories met its frustration from late 1940 s to late 1970s. The translation of some "old brand" Western contemporary literary theories, such as formalism, phenomenology and psycho-analysis, fell into stagnation, and the translation of some "new born" Western contemporary literary theories, such as hermeneutics, deconstruction, reception aestheticism and post-colonialism were completely shunned and blocked out of China. Only translation of the New Criticism, Western Marxism and structuralism continued out of the need of "denunciation" in very limited range and scale.

\section{Recovery and Revival: from the Late 1970s to the Late 1990s}

Accompanied by the implement of "opening and reform policy" from 1978, the heavy ice wrapping Western contemporary literary theories began to thaw in mainland China. China's translation of Western contemporary literary theories welcomed its recovery and revival from the late 1970 s to the end of the $20^{\text {th }}$ century.

\subsection{Translation of Formalism}

Yuan Kejia's essay "Structuralist Literary Theory" published in "Shijie Wenxue (World Literature)" 1979(2) analyzed "Russia formalism" and resumed China's translation of formalism. The next year, the translated version of Jan M. Broekman's "Structuralism" which was the first monograph introducing Russian formalism with a whole chapter was published. From then on, more and more books or essays about formalism were published in China, such as Li Huifan's translation of "Early Formalist Theory in the literature and Art of the Soviet Union" published in "Sulian Wenxue (Literature of Soviet Union)"1983(4), Chen Shengsheng and Lin Tai's "Russian Formalism" published in "Tansuo yu Zhengming (Creation and Contention)"1984(3) and Wu Xiangui's retranslation of "Russian Formalism" published in "Dangdai Wenyi Sichao (Modern Literary Magazine)" 1986(5) to name only a few. In the first decade after China's opening and reform policy, Russian formalism had been gradually acquainted by more Chinese literati. However, these primitive introductions presented different attitudes in evaluation: "Formalism' is not a pure academic term but a word containing profound political connotation." [12]Though some oversimplified understanding and negative remarks hindered and misled its reception and dissemination in China, many works on formalism had been introduced into China by Western literary works either translated or compiled by Chinese scholars because of the great theoretical value and effective aesthetic interpretation. Firstly, Western literary works translated by Chinese scholars that contains chapters on formalism include Terry Eagleton's "Western Literary Theory in the 20th Century" translated in 1983, Terence Hawkcs' "Structuralism and Semiotics" and Welleck's "Concepts of Criticism" translated in 1987, Douwe Fokkema and Elrud Ibsch's "Theories of Literature in the Twentieth Century" and Robert Hughes' "Literary Structuralism " translated in 1988,etc. Secondly, Western literary works complied by Chinese scholars that contains chapters on formalism include "Systematic Methods of Artistic Research" by Chinese department of Liaoning University in 1985, "Foundation of Methodology on Literary Criticism" by $\mathrm{Fu}$ Xiuyan and Xia Hanning in1986, "Anthology of Famous Western Artistic Theories" by Wu Lifu and Hu Jingzhi in 1986, "Lecture Collection on Methodology of Literary Criticism" by Renmin University of China in 1987, "Contemporary Western Philosophical and 
literary Thoughts" by Education Bureau of China's Ministry of Culture in 1987, "Overview of Modern Foreign Critical Methods " by Ban Lan and Wang Xiaoqin in 1987, continuation of "Methodologies on Aesthetics and Autistics" by editorial department of Research on Marxist Literature and Art Theories in 1987, "Structuralist Literary Criticism" by Zhang Bingzhen and Huang Jinkai in 1987 and "Anthology of Western Literary Theories in the Twentieth Century" by Hu Jingzhi and Zhang Shouying in1989, etc.

From the late 1980s to the late 1990s, thanks to China's stable development in the research on philosophical and social science, formalism outstood from the background of China's translation of Western contemporary literary theories. Translated monographs, such as Cai Hongbing's translation of "The Soviet Formalism Literary Theory" edited by Tzvetan Todorov and Fang Shan's translation of "Russian Formalism Literary Theory" written by Victor Shklovsky in 1989, Liu Zongci's translation of Shklovsky's "Theory of Prose" in 1994, Li Huifan and Zhang Jie's translation of "The Formal Method in Literary" by Bakhtin, became the most important works to publicize formalism. Besides, periodicals and magazines also added fuel to this fire. For example, Li Huifan's translation of Shklovsky's well-known essay "Art as Device" and "The Resurrection of Words" were published respectively in the $1^{\text {st }}$ issue of 1989 and $2^{\text {nd }}$ issue of 1993 in "Waiguo Wenxue Pinglun (Foreign Literature Review)"; Zhang Bing' translation of Tynianov's " Literary Fact" was published by "Guowai Wenxue (Foreign Literatures)" 1996(4). In short, translation of formalism reached its acme and had immeasurable influence on Chinese literature and thought.

\subsection{Translation of New Criticism}

At the end of the 1970's, translation of the New Criticism came royally into its own and became highlighted again. Zhao Yiheng once commented: "The new age of the late 1970s was a time for China to 'open window' and Chinese academic community was busy welcoming a large quantity of Western contemporary theories, among which the New Criticism was a pioneer. It was the first time that the New Criticism was deeply probed and considerable important works had been translated and published, which swept China's literary circle like a fresh wind." [13]"Case Study of American Modern Poetry" by Yang Xiling published on "Shijie Wenxue(World Literature)" 1979(6) mentioned "tension", "paradox" and "irony". Later, Yuan Kejia made a comparative illustration between the New Criticism and structuralism in "A Glimpse at Structuralist Theory".

In the 1980s, China witnessed the second summit for translation of the New Criticism after the 1930s. Many relevant works were translated and published in literary journals, monographs and collections. Firstly, some literary journals published influential essays, such as Cao Yong's retranslation of "Tradition and the Individual Talent" in "Waiguo Wenyi (Foreign Literature and Art)" 1980(3), "The
Inspiration of the New Criticism" by Yang Zhouhan in "Guowai Wenxue (Foreign Literatures)" 1981(1), and Dong Hengxun's translation of Walton Litz's idea on decline of the New Critism in "Waiguo Wenyi(Foreign Literature and Art)" 1985(5). Secondly, some translated Western monographs were published in China. For example, Liu Xiangyu's translation of "Theory of Literature" by Welleck and Warren gave rise to a heated discussion on ontology of literature and internal study, which made the New Criticism well-known in China. China Renmin University Press published Yan Yuanshu's translation of "Literary Criticism: A Short History" (by W. K. Wimsatt \& C. Brooks) in 1987 and Zhang Anqi's translation of Welleck's "A History of Modern Criticism 1750-1950" (Vol.5) in 1991. Sichuan Literature and Art Publishing House published Ding Hong and $\mathrm{Yu}$ Zheng's translation of "Conception of Literature" in 1988. Thirdly, some translated collections also enjoyed great reputation, for example, Zhao Yiheng's "Works on the New Criticism" published by China Social Sciences Press in 1988 and Shi Liang's "The New Criticism" published by Sichuan Literature and Art Publishing House in 1989 were both classic collections on the New Criticism at that time. Zhu Liyuan said in "A Survey of Development of Literary Theories and Criticism in New Age": "From the very beginning of the 'new age', China Academy gradually recognized, rethought and criticized the unilateral and univocal pattern of literary criticism. Due to the prosperity of literary creation, the previous pattern of weak and rigid literary criticism failed to interpret the new practice of literary creation." [14]It was in this context of acceptation that New Criticism gained its recovery and revival because of its traits of objectivity and scientification.

In the 1990s, translation of the New Criticism developed sustainedly. Welleck's "A History of Modern Criticism 1750-1950" (Vol.1-Vol.4) translated by Yang Qishen and his son Yang Ziwu were published by Shanghai Translation Publishing House from 1986 to 1997. "T.S. Eliot's Essays on Literature" and Richards' "Principles of Literary Criticism" published by Baihuazhou Literature and Art Press in 1994 enabled China to obtain sufficient information on the New Criticism. In 1997, Beiyue Literature and Art Press published Wang Jinhua's translation of Walter Sutton's "Modern American Criticism", which brought some Western scholars' reconsiderations on the New Criticism and also inspired Chinese scholars' rethought on it.

\subsection{Translation of Phenomenology}

Hans-Martin Sass said in his "Martin Heidegger, Bibliography and Glossary" that China didn't pay duly attention to the translation of Heidegger's works until 1982.[15] Before the 1980s, translation of phenomenology was very scarce and unsystematic in mainland China. China's translated version of classic works on phenomenology emerged in the middle of the 1980s. Ni Liangkang's translation of "Die Idee der Phaenomenologie" 
by Shanghai Translation Publishing House in 1986 is the first complete translated works on Husserl's philosophical monograph. Chen Jiaying and Wang Qingjie's translation of "Being and Time" published by Beijing Joint Publishing Company in 1999 is the first complete translated Heidegger's philosophical monograph. Besides these two books, Lü Xiang's translation of Husserl's "Phenomenology and the Crisis of Philosophy" published by International Cultural Publishing Company in 1988 and Zhang Qingxiong's translation of Husserl's "The Crisis of European Sciences and Transcendental Phenomenology" published by Shanghai Translation Publishing House in the same year were both significant translated works on phenomenology in this phase.

In the 1990s, more Western classic works on phenomenology had been translated into China. For example, works about Husserl were especially hot in this period: "The General Theory of Phenomenology" (trans. Li Youzheng, the Commercial Press, 1992), "Phenomenological Method" (trans. Ni Liangkang, Shanghai Translation Publishing House, 1994), "Ideas: General Introduction to Pure Phenomenology" (trans. Zhang Zailin, Shanxi People's Publishing House, 1994), "Selected Works by Husserl" (ed. Ni Liangkang, Shanghai Joint Publishing Press, 1997), "logic Investigation" (trans. Ni Liangkang, Shanghai Translation Publishing House, 1994, 1998 and 1999), "Philosophy as Rigorous Science" (trans. Ni Liangkang, the Commercial Press,1999), "Die Idee der Phaenomenologie" (trans. Peng Jinrun, China Social Press,1999), and "Experience and Judgment" (trans. Deng Xiaomang and Zhang Tingguo, Joint Publishing,1999) were some weighty translated works in the list. Besides, Heidegger was also appealing to Chinese scholars and many a works on his theory had been translated in this decade: Sun Zhouxing edited "Selected Works by Heidegger" (Shanghai Joint Publishing Press, 1996) that included a total of 42 articles, among which 25 were translated by Sun himself. Sun is the scholar who has translated the Maximum of original works by Heidegger in China so far. In addition to Sun's translation, some other scholars have been keen on Heidegger's thought. For instance, Peng Chunfu translated "Poetry, Language and Thought" (Culture and Art Publishing House, 1990), Qin Wei and $\mathrm{Yu}$ Hong translated "Heidegger's Nietzsche-interpretation" (Hebei People's Publishing House,1990), Cheng Qiong translated "Heidegger's Poetics" (Central China Normal University Press,1992), Gao Yuanbao translated "Poetically Man Dwells"(Shanghai Far East Publishers,1995), Xiong Wei and Wang Qingjie translated "Introduction to Metaphysics" (the Commercial Press,1996), Yang Kaichong retranslated "Introduction to Metaphysics" (China Social Sciences Press, 1999). Another conspicuous trend was some foreign researchers' monographs on Husserl's phenomenology began being translated into China in the 1990s. For example, Dutch scholar T. de Boer's "The Development of Husserl's Thought" translated by $\mathrm{Li} \mathrm{He}(J o i n t$ Publishing,1995),
American scholar Hebert Spiegelberg's "Phenomenological Movement" translated by Wang Bingwen and Zhang Jinyan( Commercial Press, 1995), German scholar Hermann Schmitz's "Neue Phanomenologie" translated by Pang Xuequan and Li Zhanglin (Shanghai Translation Publishing House, 1997) enlarged the horizon and enriched the researching materials for domestics scholars' study on phenomenology.

\subsection{Translation of Hermeneutics}

China's translation of hermeneutics began in the late 1970s, but it was in the middle of the 1980s when the surge of hermeneutics had waned and fell into a smooth development in the West that it began to be attached importance and interest in China, therefore, China's translation of hermeneutics lagged almost 20 years behind its rise in the West, and actually China's translation of hermeneutics met its watershed in the year of 1990 .

Translation of hermeneutics before 1990 was a slow accumulation and acquaintance of hermeneutics, and "Zhexue Yicong (International Philosophy Today)" played an important role in the process. It was in this journal that in 1979, 20 years after the publication of Gadamer's monumental work "Truth and Method", W . R . Boyle's works on hermeneutics was for the first time translated by Yan Hongyuan, and one year later, Греков, Леонид Иванович's "Review on 'New Schools and Problem in West Germany Philosophy" translated by Shu Bai was published, and Josef Bleicher's "Contemporary Hermeneutics: Hermeneutics as Method, Philosophy and Critique" which was regarded as the earliest comprehensive and objective commentary on hermeneutics at that time was introduced in its column "Introduction to Foreign Philosophy Books".

In the middle of the $1980 \mathrm{~s}$, the popularity of hermeneutics was embodied in two aspects. On one hand, more journals joined into introduction and discussion on hermeneutics. Beside a special in "Zhexue Yicong (International Philosophy Today)" which covered 13 translated essays by Gadamer, Heiddeger, Ricoeur and Habermas presented an overall introduction to this theory. "Theoretical Studies in Literature and Art" sponsored by East China Normal University also published many essays relevant to hermeneutics, such as Gadamer's "Aesthetics and Hermeneutics" (trans. Luo Wuheng, 1982) and its retranslated version (trans. Zhou Xian, 1986). On the other hand, more great works by Western masters on hermeneutics began to be translated into Chinese. Gadamer's "Truth and Method" (trans. Wang Caiyong) was published by Liaoning People's Publishing House in 1985. Richard Rorty's "Philosophy and the Mirror of Nature" (trans. Li Youzheng was published by Joint Publishing in 1987. Gadamer's "Reason in the Age of Science" (trans. Xue Hua) was published by International Cultural Publishing Company. Heiddeger's "Being and Time" (trans. Chen Jiaying \& Wang Qingjie) was published by Joint Pressing in 1987. Paul 
Ricoeur's "Hermeneutics and the humanities" (trans. Tao Yuanhua \& Yuan Yaodong) was published by Hebei People's Publishing House. D. C. Hoy's "The Critical Circle" (trans. Lan Jinren ) was published by Liaoning People's Publishing House. According to incomplete statistics, about 36 translated works on hermeneutics had been published and roughly formed a disseminating pattern which revolved primarily to German and secondly to France and American hermeneutics.

The 1990s witnessed an expansive growth of hermeneutic theory in China. Firstly, a comparatively complete system was finally established by translation of several Gadamer's significant works, including "The Relevance of the Beautiful and Other Essays" (trans. Zhang Zhiyang, 1991), "Truth and Method" Vol. 1 and Vol. 2 (trans. Hong Handing, 1992 \& 1999), "Plato as Portraitist" (trans. Yu Jiyuan, 1992), "Hegel's Dialectic: Five Hermeneutical Studies"(trans. Zhang Zhiwei, 1992), "Philosophical Hermeneutics"(trans. Xia Zhenping, 1994) and "Works by Gadamer"(ed. Yan Ping, trans. Deng Anqing, 1997). Among these works, publication of "Truth and Method" greatly improved and accelerated China's research on hermeneutics, and its translator Hong Handing gained much professional respect because of his eight years' endeavor in translating this great works. Secondly, some other famous Western scholars' works were also translated and made a study on hermeneutics prosperous in China. For example, Hirsch's "Validity in Interpretation" (trans. Wang Caiyong) and P. D. Juhl's "Interpretation: An Essay in the Philosophy of Literary Criticism" (trans. Wu Qizhi \& Gu Jiehong) were published respectively by Joint Pressing and Culture and Art Publishing House in 1991; Richard J. Bernstein's "Beyond Objectivism and Relativism" (trans. Guo Xiaoping, 1992) was published by Beijing Guangming Daily Press; Karl-Otto Apel's "Transformation of Philosophy" (trans. Sun Zhouxing \& Lu Xinghua,1994)was published by Shanghai Translation Pressing House; Habermas' "Knowledge and Human Interests"(trans. Guo Guanyi and Li Li, 1999) was published by Xuelin Publishing House. The publication of these translated works also contributed to flourishing of hermeneutics in China at that time.

\subsection{Translation of Reception Theory}

Reception theory began its travel in China from early the 1980s. Many Chinese famous scholars, including Qian Zhongshu, Zhang Longxi, Feng Hanjin, Zhang Li, eyed on it concurrently in the year of 1983. Qian compared Chinese literary concept "poetry is beyond interpretation" and Western reception theory in his "On the Art of Poetry" (revised version); Zhang Longxi also made a mutual explanation through an analogy between "poetry is beyond interpretation" and Western reception theory in "Wenyi Yanjiu(Literature \& Art Studies)"vol.4; Feng Hanjin took the lead to translate Italian Scholar Franco Meregalli's "On Literature Reception" and published it on "Wenxue Lilun
Yanjiu(Theoretical Studies In Literature and Art)" vol.3; Zhang Li's "Notes on 'Reception Aesthetics"” in "Wenxue Pinglun(Literary Review)"1983(10) systematically introduced reception theory's birth, development in then called East German Democratic Republic, the Federal Republic Germany and the Soviet Union.

Due to several scholars' concurrent attention in 1983, the translation of reception theory grew rapidly in the middle of the 1980s. Firstly, more and more journals were interested in the theory: "Dushu (Reading)" 1984(5) published Zhang Longxi's "Different People Have Different Views" which made a further investigation on hermeneutics, Jauss and Iser's reception aesthetics and Fish's "reader-response criticism"; "Baike Zhishi (Encyclopedic Knowledge)" 1984(9) published Zhng Li's "Reception Aesthetics: A New Method for Literature Analysis"; "Jiangsu Meixue Tongxun (Jiangsu Aesthetic Report)" 1985(1) published Sun Jing's translation of W. Fokkema and Elrud Kunne-Ibsch's "Reception to Literature: Theory and Practice of 'Reception Aesthetics"; "Wenxue Lilun Yanjiu(Theoretical Studies In Literature and Art)" 1985(2) published Luo Tilun's translation of Grimm's "Introduction to Reception Aesthetics"; "Wenyi Yanjiu(Literature \& Art Studies)" 1985(7) published Zhang Guofeng's "A New Literary Theory Abroad: Reception Aesthetics" which gave a detailed introduction to Jauss, Iser and Naumann's theories; "Du Shu(Reading)" 1987(1) published Liu Xiaofeng's “The Real Purpose of Reception Aesthetics". Secondly, several important monographs and collections on reception theory were published: Zhou Ning and Jin Yuanpu's translation of Jauss and Holub's "Receptional Aesthetic and Reception Theory" published by Liaoning People's Publishing House in 1987 is the first translated works on reception theory in China. Later, Huo Guihuan's translation of Iser's “The Act of Reading" was published by China Renmin University Press in 1988. One year later, many other relevant works were published, including "Collection of Translated Works on Reception Aesthetics" (ed. Liu Xiaofeng, Joint Pressing), "Reception Aesthetics" (ed. Zhang Tingzhen, Sichuan Literature and Art Publishing House), "Reader Response Criticism_-From Formalism to Post-Structuralism" (trans. Liu Feng \& Yuan Xianjun, Culture and Art Publishing House).

In the 1990s, reception theory got to be even more popular in Chinese academic community. In 1991, two retranslated versions of Iser's masterpiece "The Act of Reading" were published, one was translated by Jin Yuanpu and Zhou Ning (China Social Sciences Press), the other was translated Jin Huimin, Zhang Peng, Zhang Ying and Yi Xiaoming (Hunan Literature and Art Publishing House). As one of the most representative and thought-provoking masterpieces, the retranslation of "The Act of Reading" made a great contribution to China's connection to international criticism trend. In the following years, Pan Guoqing's translation of Norman Holland's "The Dynamics of Literary Response" was published by Shanghai People's Publishing House; Zhu 
Liyuan's translation of Jauss' "Aesthetic Experience and Literary Hermeneutics" was published by The Writers Press in 1992; Wen Chuan translated many of Stanly Fish's influential essays and put them in a collection named "Reader Response Criticism: Theory and Practice" which was published by the Chinese Academy of Social Sciences Publishing House in 1998. In a nutshell, through 20 years translation of reception theory, China gradually followed the international literary theory's trend from works-oriented to writer-oriented, and then to reader-oriented.

\subsection{Translation of Structuralism}

"From the middle of the 1970s, because of Barthes and Derrida's opposition and abandon, structuralism became outmoded in the West. However, contrary to its fate in the West, when structuralism was imported into China, it was treated as a lovely child born in a new age and gained much care and attention, so a lot of related works were translated and spread widely at that time. "[16] In 1979, Yuan Kejia's essay "Introduction to Structuralist Literature" on "Shijie Wenxue (World Literature)" resumed China's interest to structuralism. Although Yuan hold a positive attitude to it, he still believed that this theory actually was "an ossified and mechanical system regardless of social and historical conditions and author's worldview." He further pointed: "Structuralism makes literature into water without a source or a tree without roots, because it is separated from the thought and art contained in the works itself." One year later, Yuan translated Barthes's "The Structuralism Activity" and published it in "Wenyi Lilun Yanjiu (Theoretical Studies in Literature and Art)" vol.2. In the same year, China's first translated monograph on structuralism, Li Youzheng's translation of Piaget's "Structuralism", was published by the Commercial Press. The publication of "Structuralism" is a milestone for the wide-spread for this Western literary theory in China. Since then, many Chinese scholars began to publish essays on structuralism on various journals. Among them, Zhang Longxi made him distinctive by publishing four essays on "Dushu (Reading)" in 1983, making a comprehensive research on structuralism by introducing structuralist linguistics, structuralist poetics, structuralist narration and Czech structuralist theory. Spring for structuralism came late to China, but it came after all.

From the middle of 1980 s, a craze for "methodology" swept Chinese literature research, which stimulated translation of structuralism like a catalyst. Many significant works on structuralism were translated out of Chinese scholars' passion for scientific analytical methods on literature. Piaget's "Structuralism" was retranslated by $\mathrm{Li}$ Liansheng and published by the Commercial Press in 1984; Roland Barthes' "Elements of Semiology" was translated by Dong Xuewen and published by Liaoning People's Publishing House in 1987; Lévi-Srauss" "The Savage Mind" was translated by $\mathrm{Li}$ Youzheng and published by the Commercial Press in 1987; Terence Hawks' "Structuralism
And Semiotics" was translated by Qu Tiepeng and published by Shanghai Translation Publishing House in 1987; Robert Scholes' "Structuralism in Literature" was translated by Liu $\mathrm{Yu}$ and published by Joint Publishing in 1988; Edith Kurzweil" s "The Age of Structuralism: Lévi-Srauss to Foucault" was translated by Yin Dayi and published by Shanghai Translation Publishing House in 1988; "Western Literary Theory in the Twentieth Century" which included some translated masterpieces by Barthes, Todorov, Genette and Greimas was edited by Hu Jingzhi and Zhang Shouying and published by China Social Sciences Publishing House in 1989. In addition to the works mentioned above, Terry Eagleton's "Literary Theory: An Introduction" (trans. Wang Fengzhen, China Social Sciences Press,1988) and Fokkema and Ibsch's "Theories of Literature in the Twentieth Century" (trans. Lin Shuwu, Joint Pressing, 1988) both introduced structuralism's origin and development, theory and practice, representatives and definitions. Translation of structuralism reached its acme at the end of $1980 \mathrm{~s}$, which drove the upsurge of researching on it throughout the country.

In the 1990s, under the impact of some other Western literary theories, China's craze for structuralism waned. But the publication of Genette's "Narrative Discourse, New Narrative Discourse" (trans. Wang Wenrong, China Social Sciences Press, 1990) and Lévi-Srauss' "Structural Anthropology" (trans. Xie Weiyang, Shanghai Translation Publishing House, 1995) to some extent, brought about a turnabout for it. Chen Taisheng once commented: "In the 1990s, post-modernism, mass culture and humanism became in heated discussion among Chinese literati. Meanwhile, post-structuralism, feminism, and post-colonialism were quickly imported into China from remote West. Some critical theories that once were popular in the 1980s were consequently given short shrift. However, Chinese scholar's interest in structuralism never really went cold, since they felt structuralism still haunted in many latest Western theories."'[17]

\subsection{Translation of Deconstruction}

So-called "deconstruction" has a subtle connection with structuralism because its continuity and treason to structuralism. It didn't gain duly attention in the 1980s and even 1990s, with only few translated excerptions published in some literary theory books. For example, translated version of Derrida's "Before the Law" was included in "Contemporary Western Art and Literature" by Zhou Xian; Translated version of Derrida's "The Supplement of Copula: Philosophy before Linguistics" and Jonathan Culler's "On Deconstruction" were included in "Anthology of Western Literary Theories in the Twentieth Century" by Hu Jingzhi and Zhang Shouying; Translated version of Christopher Norris' "Jacques Derrida" was included in "Mythology on Aesthetics and Art" by Zhu Liyuan and Cheng Weijie; Translated version of Derrida's "Structure, Sign, and Play in the Discourse of the Human Sciences" was included in 
"Contemporary Foreign Philosophy". Before the middle of 1980 s, deconstruction had been translated into China only as a necessary composition of contemporary Western literary theory, without drawing much attention to its own. Though China's publication of translated version of Eagleton's "Western Literary Theory in the 20th Century" (1983), Ann Jefferson and David Robey's "Modern Literary Theory: A Comparative Introduction" and Rory Ryan's "A Reader's Guide to Contemporary Literary Theory" as well as "Review on Western Literary Theory in the Twentieth Century" edited by Zhang Longxi all included chapters to make exclusive introduction of Derrida or the "Yale School", compared with deconstruction's power in Western critical circle, its translation then in China was not sufficient at all.

At the end of 1990s, "The Rhetoric of Drugs: An Interview" (trans. He Peiqun, Shanghai People's Publishing House, 1997) was the first book written by Derrida that has been finally translated and published in China. One year later, $\mathrm{Lu}$ Yang's translation of Jonathan Culler's "On Deconstruction: Theory and Criticism after Structuralism" was published by Intellectual Library Press, and Zhao Xingguo's translation of Derrida's "Acts of Literature" was published by China Social Sciences Publishing House. Translation of Derrida's works seized opportunity for its development in 1999 and four books were translated and published this year, including "Of Grammatology" (trans. Wang Jiatang, Shanghai Translation Publishing House), "Memoires for Paul de Man" (trans. Jiang Zihua, Central Edition and Translation Publishing House), "Specters of Marx: The State of the Debt, the Work of Mourning, and the New International" (trans. He Yiqun, China Renmin University Press) and "'Speech and Phenomena' and Other Essays on Husserl's Theory of Signs" (trans. Du Xiaozhen, the Commercial Press). Up till then, deconstruction came royally into its own with many Chinese scholars' devotion to its translation.

\subsection{Translation of Psychoanalysis}

China's translation of psychoanalysis was almost consummated in the 1980s. Firstly, translation of Freud's works gave rise to a "Freud Fever" in China: the rendering of "Introductory Lectures on Psycho-Analysis", "Totem and Taboo: Resemblances between the Psychic Lives of Savages and Neurotics", "The Ego and the Id", "Group Psychology and the Analysis of the Ego", "Three Essays on the Theory of Sexuality", "Beyond the Pleasure Principle" and "New Introductory Lectures on Psycho-Analysis" swept China with irresistible power. Even translation of some Freud's less important works also contributed a lot to China's literary criticism: "Autobiography of Sigmund Freud" (trans. Zhang Ji \& Zhuo Rufei, Liaoning People's Publishing House, 1986), "Fragment of an Analysis of a Case of Hysteria (the Dora case history)" (trans. Wen Rongguang, China Folk Literature and Art Publishing House, 1986), "A general Selection from the Works of Sigmund Freud" (ed. John Rickman, trans. He Mingming, Sichuan People's Publishing House, 1986), “The
Psychopathology of Everyday Life" (trans. Lin Keming, Zhejiang Literature and Art Publishing House \& Gansu People's Publishing House, 1986), "An Outline of Psycho-Analysis"(trans. Liu Futang, Anhui Literature and Art Publishing House,1987), "Moses and Monotheism"(trans. Li Zhankai, Joint Pressing,1987), and "The Interpretation of Dreams" (trans. Chen Fang, Shanxi People's Publishing House,1987)were some matchsticks added in the conflagration of psychoanalysis in China. Secondly, translation of Erich Fromm's works was also a cornerstone for the popularity of psychoanalysis in China. "The Art of Loving" (trans. Hu Xiaochun \& Wang Jianlang, Anhui People's Publishing House, 1987), "The Sane Society" (trans. Ouyang Qian, China Federation of Literary and Art Circles Publishing Corporation, 1988), "The Crisis of Psychoanalysis" (trans. Xu Junda \& Xu Junnong, International Cultural Publishing Company, 1988), "Psychoanalysis and Religion"(trans. Deng Weichuan, Yunnan People's Publishing House, 1988)and "Spiritual Analyse of Dream"(trans. Ye Songshou, Guangming Daily Press, 1988) fanned psychoanalysis into higher flame. Lastly, Wangning's translation of Frederick J. Hoffman's "Freudianism and the Literary Mind" (Joint Pressing, 1987) provided Chinese academia with previous and authoritative materials on Western scholastic research on psychoanalysis.

In the 1990s, China's enthusiasm for translating psychoanalysis continued unabated. Freud's theory was constructed more systematically. First of all, some Freud's works were retranslated and improved due to China's scholars' intensive and comprehensive understanding about psychoanalysis. For example, "The Interpretation of Dreams", was once retranslated repeatedly by many scholars, including Sun Mingzhi, Dan Ning, Peng Runjjin, lai Qiwan, Fu Chuanxiao and Luo Sheng. "Three Essays on the Theory of Sexuality" was also retranslated by Teng Shouyo, Luo Sheng, Liu Congyu and Ju Fuwei respectively. Secondly, "Collected Works by Freud"'(ed. Che Wenbo, Chang Chun Publishing House,1998), which included 5 books and covered 38 Freud's classic works, was publicly acknowledged as the most complete collection on Freud's thought in China. Last but not least, More Fromm's works were translated into China, with "Zen Buddhism and Psychoanalysis" (trans. Wang Leiquan \& Feng Chuan, Guizhou People's Publishing House, 1990) as the most typical example.

\subsection{Translation of Post-colonialism}

Post-colonialism's travel in China began from early the1990s when Zhang Jingyuan's "This and That: Review on Edward Said's 'Orientalism"” published on "Wenxue Pinglun (Literary Review)"1990(1) made the earliest introduction on post-colonialism in China.

Along with the penetrating change in China's academic community, post-colonialism developed promptly in the middle 1990s. Publication of Said's "Culture and 
Imperialism" in April, 1993 spurred "Dushu (Reading)" to publish Zhang Kuan's "Heterogeneous Ethnic Groups in Europeans and Americans" and Qian Jun's "Review of Culture and Imperialism by Edward Said" on its heels. In 1994, many weighty journals, such as "Dushu (Reading)", "Zhongshan", "Wenyi Zhengming(Contention on Literature and Art)", "Dongfang (The East)", "Guangming Ribao (Guangming Daily)" and "Wenyi Bao (Paper of Literature and Art)", published essays or interviews on post-colonialism invariably. Many Chinese Frontiers in literary theory research, including Wang Yichuan, Chen Xiaoming, Zhang Yiwu, Dai Jinhua, Wangning, Wang Yuechuan, Zhang Fa, Tao Dongfeng, Yang Naiqiao and Chen Yuehong, actively participated in the heated discussion on this novel theory and formed an academic climate of "Said craze". It was in this climate where a considerable number of Chinese scholars began to translate works on post-colonialism.

Regarding individual contribution, Wang Ning, as the most remarkable scholar on post-colonialism study in China, set a trend of post-colonialist criticism research, and then many a Chinese scholar just followed this trend and made this literary theory well-known in China. In terms of periodical, "Zhongwai Wenhua yu Wenlun(Chinese and Foreign Cultural and Literary Theory)" paved the way for further development of post-colonialism in China. "Chinese and Foreign Cultural and Literary Theory"1996(1) published an interview with Radhakrishnan entitled "The 'Post-colonialism' Implies the Continuity of Colonial Times", Yi dan and Zhang Hong's two essays on "Overstepping the Cultural Dilemma of Colonial Culture" and "Post-colonial Theory" translated by Wang Xiaolu. "Chinese and Foreign Cultural and Literary Theory" 1996(2) continued its discussion on post-colonialism by publishing Wang Ning and Wang Fengzhen's insight on "Post-colonialism and Chinese Contemporary Culture", Li Jie's article "Why "East is not East", Zhang Hong's response to Yi Dan's inquiry in "Review on the Cultural Context for 'Colonialization"” and Wang Xiaolu's translation of Said's biography and academic accomplishment. Before long, "Wenyi Yanjiu (Literature \& Art Studies)" 1997(3) published Luo Gang's "On some Problems in Colonial and Post-colonial Discourses" which introduced Fredrick Jameson, Arif Dirlik and Aijaz Ahmad's views on post-colonialism. In terms of translated works, 1999 was a "bumper harvest" for China's translation of post-colonialist works: after Elleke Boehmer's "Colonial and Postcolonial Literature" (trans. Sheng Ning \& Han Min, Liaoning People's Publishing House, 1998) provided some excellent paradigms for Chinese scholars' employment of post-colonialist theory in textual study, "Post-colonialist Theory and Cultural Criticism" edited by Zhang Jingyuan was published by Peking University Press in January, Excerpts in "Culture and Imperialism" co-translated by Xie Shaobo and Han Gang was published by Shanghai People's Publishing House in January, "Theory of Post-colonialist
Culture" edited by Luo Gang and Liu Xiangyu was published by China Social Sciences Publishing House in April (Zhang and Luo's argumentation on post-colonialism can make up for each other's deficiencies.), "Orientalism" translated by Wang Yugen was published by Joint Pressing in May, which was a monumental event in China's translation of pos-colonialism; "Selected Essays by Edward Said" translated by Xie Shaobo and Han Gang was published by China Social Sciences Press in August. In a word, in the last year of the $20^{\text {th }}$ century, China's research on post-colonialism made a great breakthrough and translation of this theory finally expanded from Edward Said to "the three musketeers" (Edward Said, Spivak and Homi K. Bhabha) to Fredrick Jameson, John Tomlinson, Bell Ashcroft, Gareth Griffiths and Helen Tiffin. Translation of post-colonialism still maintains this sound momentum and this theory is now like one of the brightest stars among the constellation of Western contemporary literary theories.

\subsection{Translation of West Marxism}

With the ideological chains and fetters on West Marxism broken by "reform and opening up", translation of West Marxism turned the corner in the 1980s. From1980, many works on West Marxism were successively translated into Chinese. For example, S.S. Prawer's "Karl Marx and World Literature" (trans. Mei Shaowu, Fu Weici and Dong Leshan, Joint Pressing, Eagleton's "Marxism and Literary Criticism" (trans. Wen Bao, People's Literature Press), together with "Research on Sartre" (ed. Liu Mingjiu, China Social Sciences Press) greatly changed previous partial understanding about West Marxism in Chinese academic community. In1982, Xu Chongwen who was called "the first man on Chinese 'West Marxism' study" published his monograph simply named "West Marxism" (Tianjin People's Publishing House). His book was like a stone thrown into a lake which made a big splash, causing many authoritative magazines and journals competitively publish articles or reviews on his book. Sponsored by Chongqing Publishing House, Xu edited China's first series on West Marxism Research, including 42 books in total, published in 1989, 1990 and 1997. Xu's commitment to West Marxism enables China to understand this theory more thoroughly and systematically. In addition, "Selected Essays on West Marxist Aesthetics" (ed. Lu Meilin, Lijiang Publishing House, 1988), as the fullest collection on West Marxist Criticism works at home, also aided the dissemination of West Marxism in China.

In the 1990s, China's interest in West Marxism turned from translation to research. "A New Dimension in Modern Aesthetics: a Collection of Essays on West Marxist Aesthetics" (ed. Dong Xuewen, Rong Wei, Peking University Press, 1990) include 11 West Marxists' works. The collection made more researching materials available to Chinese scholars, and hence was hailed as one of most much-touted achievements at that time, In October of 1990, 
China's first symposium on West Marxism was held in Chengdu, Sichuan. Delegates exchanged ideas on the definition, category and features of West Marxism and discussed on some important theoretical problems put forward by renowned representatives in this field. After this Symposium, a mass fervor on theoretical research on West Marxism was ignited.

"Reform and opening up" promised a free academic atmosphere, where the translation of West contemporary literary theories was left almost unbounded. Because the hunger and thirst for Western thoughts once was suppressed in the second phase now can be freely satisfied in the third phase, a diversity of Western contemporary literary theories at different ages and places were all translated and implanted into China. In only two decades, the diachronic Western contemporary literary theories had been crammed into a synchronic network in China. China's translation of formalism, New Criticism, phenomenology, hermeneutics, reception theory, structuralism, deconstruction, psychoanalysis, post-colonialism and West Marxism developed unprecedentedly. This "explosive" growth was factually a rebound and rebellion to the previous excessively enclosed and oppressive guidelines for art and literature in China.

\section{The Sustained Development and New Turn: from the Beginning of the 21st Century till Now}

Due to the emergence of global contexture and rise of China as a big power in the developing countries, China's translation of Western contemporary literary theories experienced a blowout in the 21 st century. On the one hand, the economic and political connection to the West facilitates China's cultural communication with Western world; on the other hand, China's opposition to unitary cultural hegemony and active encouragement of cultural pluralism accelerates the integration of global economy and politics. However, in this intertwined coexistence of politics, economics and culture, as a result of the variation of China's reception context and international situation, translation of Western contemporary literary theories has presented or is now forming some diversions and twists.

\subsection{Some Western Contemporary Literary Theories is Confronted with the Crisis of Ardor Diminishment}

\subsubsection{Translation of New Criticism}

In 2000, C. K. Ogden and I. A. Richards' masterpiece "The Meaning of Meaning: A Study of the Influence of Language upon Thought and of the Science of Symbolism" was translated by Bai Renli and Guo Qingzhu and published by Beijing Normal University Press; In 2003, "Richards: Science and Poetry" was edited by $\mathrm{Xu}$ Baogeng and published by Tsinghua University Press; In 2006, Ranson's
"The New Criticism" was translated by Wang Labao and Zhang Zhe and published by Jiangsu Education Publishing House; From 2002 to 2006, Welleck's “A History of Modern Criticism" Vols 5-8 were co-translated by Yang Qishen and his son Yang Ziwu and published by Shanghai Translation Publishing House. In autumn of 2009, the revised translated version of "A History of Modern Criticism" Vols 1-8 were published by Shanghai Translation Publishing House as a "gift" for the PRC's $60^{\text {th }}$ birthday presented by Century Publishing Group. However, despite the continuity of China's translation of the New Criticism in the $21^{\text {st }}$ century, China's passion for New Criticism was unavoidably dissolved by the impact from some other more pioneering theories. The New Criticism, as a theory that is not "new" any more, is now fading away in China's translation of Western contemporary literary criticism. Zhang Hui is one of those scholars who have been aware of the change. She pointed out: "Along with the import of 'post-modern' theories in the 1990s, translation of New Criticism was quite less 'remarkable' than that in the 1940s. This is caused by the impulse and momentum for latest theories in Chinese Academy."[18]

\subsubsection{Translation of Formalism}

Some essays and works on formalism were kept on being translated in the $21^{\text {st }}$ century, including Raman Selden's "The Theory of Criticism: From Plato to the Present" (trans. Liu Xiangyu \& Chen Yongguo, Peking University Press, 2000), Shklovsky's “Crisis in Personal Value"(trans. Lu Zhaoming, "Eluosi Wenyi" or "Russian Literature \& Arts", 2001), Roger Fayolle's "Criticism: Method and History"'(trans. Huai Yu, Baihua Literature and Art Publishing House,2002), Todorov's "Criticism of Criticism"(trans. Wang Dongliang \& Wang Chenyang, Joint Pressing,2002), "Problems and Perspectives: the Comprehensive Study on 20th Century Literary Theory"(ed. Douwe Fokkema, trans. Shi Zhongyi, Henan university press, 2010), etc. Chinese academia's interest has been transferred from translation to interpretation and exploration, and translation of formalism is not so hot as before. "In this century, China's literary theory researchers are not so passionate as they were in the 1980s, but many opinions and methods in Russian formalism, Anglo-American New Critics and French structuralism have been turned into some general knowledge and common sense in literary theory study. In other words, many useful formalist literary theories, as some compositions, have already been integrated and mingled into the present literary theory study." [19]

\subsection{Some "Old" Western Contemporary Literary Theories have Generated New Attractions in Translation}

\subsubsection{Translation of Structuralism}

In 2006, "Literary Theory: an Essential Reader" edited by Yan Jia was published by China Renmin University Press. 
This book included Symour Chatman's "Story and Discourse" (trans. Huang Hui), the first chapter of Genette's "Narrative Discourse: An Essay in Method" (trans. Pan Chunlin) and some other Western latest theories after the 1980s. In 2009, on the base of "Collection of Gerard Genette's Essays" (trans. Shi Zhongyi, Baihua Literature and Art Publishing House, 2001), Shi Zhongyi's "Collection of Gerard Genette's Essays: Collection of Translated Literary Criticism Essays" (Henan university press, 2009) added 12 essays written by some masters like Barthes, Griffiths, Todorov, etc. In 2013, Genette's neWest accomplishment in cross-media narration, "Metalepse. De la Figure a la Fiction" (trans. Wu Kangru, Lijiang Publishing House) was warmly welcomed by Chinese scholars after a prolonged expectation.

Because the great discussion on humanistic spirits in the 1990s demanded a concentration on the value of humanist rationality, while structuralist literary theory's feature of scientism and tendency of counter-subjectivity were both against the mainstream of humanitarian concern in literary criticism in this new era, furthermore, the sudden rise of cultural study and fall of structuralism in the West, as well as the distraction from newer and more fashionable theories, Chinese academia's attention on structuralism in the $21^{\text {st }}$ century has been considerably reduced compared with that of the 1980s and 1990s. The development of literary theory has factually proved the researching mode advocated by structuralism has been dismantled by history, but it is undeniable that as the third Western ideological trend following Anglo-American New Criticism and French phenomenology, structuralism once surpassed ideological differences and influenced almost all countries throughout the world. Feng Zongxin once remarked: "The introduction of Structuralism to China has gone through several lengthy and complicated stages, from sporadic translations, superficial discussion and reckless criticism to systematic translations, critical reception, creative application and development, and has greatly influenced many disciplines and fields in China's humanities and social sciences."'[20] Judging from the present situation, despite the adversity, translation of structuralism will never disappear in China in short period, since structuralist narratology, as a new point of attraction concerned with structuralism is now rising.

\subsubsection{Translation of Psycho-analysis}

Psychoanalysis, as the first Western literary theory translated into China, had developed unprecedently in the 1980s and 1990s. Although it is quite an "old" theory, it still keeps its momentum in Chinese academia by presenting some new ideas, among which Jacques Lacan's idea is typically a new attraction to Chinese scholars.

In the first place, some Freud's works are further disseminated by translated Chinese versions or introduction of their English editions. "Interpretation of Dreams" was edited by Feng Guochao (China Social Press, 2000), and again translated by Miao Dongqing(Yanbian People's Publishing House, 2001) and Luo Lin (Jiu Zhou Press, 2004).
"Introductory Lectures on Psycho-Analysis" was translated by Peng Shun (Shanxi People's Publishing House, 2001) and its version was published by Hainan Publishing House in the same year. "Civilization and its Discontents" was translated by Yan Zhijun (Hebei Education Press, 2003) and its English version was published by Shanghai Foreign Language Education Press in the same year. Besides, "Fred's Pyscho-philosophy", as a collection of Freud's many works of his thought on psychology and philosophy, was translated by Yang Shaogang (Jiuzhou Press, 2003).

In the second place, more Western scholars' works on psycho-analysis are kept on being translated into China. Julia Kristeva's "Powers of Horror: An Essay on Abjection" (trans. Zhang Xinmu) was published by Joint Pressing in 2001; Michael St. Clair's "Object Relations and Self Psychology" (trans. Jia Xiaoming and Su Xiaobo) was published by Chinese light industry press in 2002 . The former combined semiotics and psychoanalysis to explore human's affective phenomena, the latter introduced object relation and self-psychology, which are two representative concepts in modern psychoanalysis. Both the books narrow the gap in psychoanalysis between China and the West. Margaret Muckenhoupt's "Sigmund Freud: Explorer of the Unconscious" (trans. Pan Qingqing) was published by Shaanxi Normal University Press in 2004. Jean Bellemin-Noel's "La Psychanalyse du texte litteraire: Introduction aux lectures critiques inspirees de Freud"(trans. Li Shuhong) was published by Tianjin People's Publishing House in 2004. The most remarkable event for translation of psychoanalysis in this period was the publication of Fromm's "The Forgotten Language" (trans. Guo Yiyao, International Cultural Publishing Company, 2007) which consisted of many classic works by Freud, Fromm, Lacan, Adler, Jung and Horney.

At last, Lacan's theory is winning more and more attention and being a new hot spot in translation of psychoanalysis in China. "Collection of Works by Lacan" (trans. Zhu Xiaoquan, Joint Pressing, 2001) is the earliest and most fundamental document for Chinese scholars' study on Lacan. In addition, Slavoj Zizek's "Looking Awry: An Introduction to Jacques Lacan through Popular Culture" (trans. Ji Guangmao, Zhejiang University Press, 2011), Sean Homer's "Jacques Lacan"(trans. Li Xinyu, Chongqing University Press, 2014) and Darian Leader's "Introducing Lacan"(trans. Li Xinyu, Contemporary China Pressing House, 2014) are the latest translated works on Lacan in China. Wang Ning once remarked: "when a traditionally people-oriented psychoanalysis criticism is now declining, French structural psychoanalyst Jacques Lacan suddenly rises as a new force by transforming and reinterpretation of Freud's theories. He rejuvenates this criticism theory and saves it from danger." [21] With Lacan's theory being hot in the West, translated works on his theories are getting to be on wings in China.

\subsection{Some Western Literary Theories are Becoming New Hotspots in Translation}




\subsubsection{Translation of Deconstruction}

'Because of Post-colonialism's inherent tension, disposition of criticism and openness, it will have far-reaching influence on Chinese scholars, especially on those young scholars. Once the younger generation of Chinese scholars grows to be the mainstream and cornerstone of China Academy and begins their synchronized conversation with Western Academy, to some extent post-structuralism would inevitably be the foundation of literal science in the next stage." [22]Indeed, contrary to the destiny of traditional structuralism which is being dissolved in China's translation, the translation of post-structuralism or deconstruction is now gaining its power to develop in rush and dash, because it is in accordance with the trend of "decentralization" and "multiculturalism" in the $21^{\text {st }}$ century. In such a macro-situation, many classic works on deconstruction, such as Derrida's "Writing and Difference" (trans. Zhang Ning, Joint Pressing, 2001), Derrida's "For What Tomorrow...A Dialogue, with Elisabeth Roudinesco" (trans. Su Xu, Citic Press, 2002), "Edmund Husserl's Origin of Geometry: An Introduction" (trans. Fang Xianghong, Nanjing University Press, 2004), Derrida's "Positions" (trans. She Biping, Joint Pressing, 2004), "Contention Between Germany and France: Dialogue Between Gadamer and Derrida" (trans. Sun Zhouxing \& Sun Shanchun, Tongji University Press, 2004) and Roland Barthes' "A Lover's Discourse: Fragments" (trans. Wang Yaojin \& Wu Peirong, Shanghai People's Publishing House, 2009), were successively translated into China.

Works on deconstruction from American Yale school were also translated into China, which added to China's understanding about deconstruction criticism and attracted more scholars to plunge themselves into the swim. In addition to publication of Hillis Miller's "Restate Deconstruction" (trans. Guo Yingjian, China Social Sciences Press, 2000) and "Reading Narration" (trans. Shen Dan, Peking University Press, 2002), some works by critics, such as Lyotard, Foucault and Jameson who put forward more complex theories concerned with post-modernity and post-structuralism were translated successively into China and quickly became the focus of China's Academy.

\subsubsection{Translation of Post-colonialism}

As a world-renowned literary theory founded on the basis of post-modernism, the translation of post-colonialism has been in continuous rise. Yang Naiqiao's translation of "Post-colonial Criticism" by Gilbert was published by Beijing University press in June of 2001; Chen Zhongdan's translation of "Post-colonialism Criticism: Context, Practice and Politics" was published by Nanjing university press in July of this year. Shan Dexing's translation of "On Intellectuals" by Said published by Joint Pressing in April of 2004 drew much public attention and had great influence on China's literati. Li Kun's translation of "Culture and Imperialism " published by Joint Pressing in October of 2003 elaborated the writing of the third world concerned with colonial and post-colonial literature. The publication of translated "Culture and Imperialism" showed a good example for utilizing post-colonialist theory into literary criticism and propelled practice of post-colonialism in China's literary criticism.

Translation of post-colonialism gained more obvious development after 2010, with a multitude of relevant works being translated and published. Rong Xinfang's translation of Robert J. C. Young's "Postcolonialism: A Very Short Introduction" and Yan Beiwen's translation of Spivak's "Critique of Postcolonial Reason: Towards a History of the Vanishing Present" were published by Yilin Press in 2013 and 2014. Accompanied with the international popularity of Post-colonialism and the heated discussion on it at home, it was likely that translation of post-colonialism would be a hotspot in following decades.

\subsubsection{Translation of Phenomenology}

In the $21^{\text {st }}$ century, China's translation of phenomenology is in sustainable development. To begin with, Chinese scholars have translated many Husserl's books, such as "On the Phenomenology of the Consciousness of Internal Time" (trans. Yang Fubin, Huaxia Publishing House, 2000), "The Crisis of European Sciences and Transcendental Philosophy"(trans. Wang Bingwen, the Commercial Press, 2001), "Cartesian Meditations" (trans. Zhang Guoting, China City Press, 2002), "Life-world Phenomenology" (trans. Ni Liangkang \& Zhang Guoting, Shanghai Translation Publishing House, 2002), and "Ethics and Value Theory" (trans. Ai Silin \& An Shitong, China City Press, 2002). Next, Sun Zhouxing translated many Heidegger's works, including "Elucidations of Holderlin's Poetry" (the Commercial Press, 2000) and "Nietzsche" Vols 1-2 (the Commercial Press, 2002). Lastly, many Western scholars' works on Husserl's phenomenology have been translated. The publication of Victor Velarde's "On Husserl” (trans. Yang Fubin, Zhonghua Book Company, 2002), Imamura Hitoshi's “Adventurers Who Select Contemporary Thought of Contemporary Thought Source of Marx, Nietzsche, Freud, Husserl" (trans. Bian Chongdao, Hebei Educational Publishing House, 2007) and AD Smith's "Husserl and The Cartesian Meditations" (trans. Zhao Yulan, Guangxi Normal University Press, 2007) all contribute a lot to open the eyes of China's scholars. In brief, translation of phenomenology has experienced lots of ups and downs in China in the past 100 years, now it can triumphantly announce its success in gaining favor from Chinese Academy.

\subsection{Some Western Contemporary Literary Theories are to be Translated Increasingly}

\subsubsection{Translation of Reception Theory}

In the $21^{\text {st }}$ century, China's hospitality to reception theory remains the same as that of the third phase. Iser's "The Fictive and Imaginary: Charting Literary Anthropology" (trans. Chen Dingjia and Wang Zhenglong) was published by 
Jilin People's Publishing Press in 2003. The publication of this great work changed Chinese academia's previous misunderstanding of the transformation in Iser's thought caused by lack of first-handed or timely translated documents. What's more, "Course of Literary Criticism" (ed. Zhou Zhonghou, China Renmin University Press, 2002) and "Course of Literary Criticism Practice" (ed. Zhao Yanqiu, Central South University Press, 2007) introduced reception aesthetics with separate chapter, which widely popularized the theory among young scholars in China's higher education. Iser's last book "How to Do Theory"(trans. Zhu Gang, Gu Tingting, Pan Yusha, Nanjing University Press, 2008 ) was published only three years after its publication in America. Wang Wei thought that China's passion for reception aesthetics had reduced due to the impact from more fashionable post-modern literary theories. He took the translation of "Poetics and Hermeneutics" as example and said "The most significant researching achievement of 'Konstanz School', which contains as many as 6,000 pages in 12 volumes, has not yet been translated into China, moreover, it is impossible to be translated into China in foreseeable future, and hence Chinese intellectuals' horizon is to be limited by this objective limitation".[23] However, we have reasons to believe that since such a huge treasury is left intact from translation, translation of reception theory is to be guaranteed a promising future in China, compared with those theories which have already been translated fully and repeatedly.

\subsubsection{Translation of Hermeneutics}

In the $21^{\text {st }}$ century, translation of hermeneutics in China follows closely to its development in the West, and the two are almost synchronized, especially in some academic websites. "Understanding and Interpretation: Classic Essays on Hermeneutics" (ed. Hong Handing, Oriental Press, 2001) is China's first and most complete collection on Western hermeneutics, including essays by some famous Western scholars in this field from Astor, Schleiermacher, Dilthey to Heidegger, Gadamer, Habermas, Apel, Betti, Ricoeur and Rorty. Besides, Hong Handing's "Hermeneutics: its Origin and Development" (People's Publishing House) and "Truth of Interpretation: a Guideline to Gadamer's "Truth and Method" (Shandong People's Publishing House), He Weiping's "A Path to Hermeneutic Dialectics: A research on Gadamer's Philosophy" (Joint Pressing), Li Qingliang's "China's Hermeneutics" (Hunan Normal University Press) are also important fruits of Chinese scholars' introduction and research of hermeneutics. Just like translation of reception theory, with so huge a treasury left undigged and the further development of the theory in West, it is likely that translation of hermeneutics will grow in following years.

\subsubsection{Translation of West Marxism}

Along with domestic research on West Marxism going deeper than before, China's translation on this theory grows steadily in the $21^{\text {st }}$ century. The academic research is the biggest driving force to urge Chinese scholars to translate this arcane theory. In November of 2003 , the $20^{\text {th }}$ anniversary of National Marxism Literary Theory Society and a symposium named "Foreign Marxism Literary Theory and Construction of China's Literary Theory" was held at SouthWestern Normal University; In June of 2004, a symposium on "Jameson and China" was held in Beijing. China Remin University Press took the occasion to publish "Jameson Collection (vols1-4)" (ed. Wang Fengzhen) which included many Jameson's essays that were translated into Chinese for the first time. The collection, around four themes, including "New Marxism", "Criticism Theory and Narration Interpretation", "Culture Study and Politics Research" and "Modernism, Postmodernism and Globalization", became valuable materials for Chinese scholars' further and deeper acquaintance of latest Western theoretical development in Marxism.

Later, more relevant works were published in China, including "New Marxist Literature and Art" (ed. Pan Tianqiang, Fudan University Press, 2005), Feng Xianguang's "Research of Ontological Twentieth Century West Marxist Theory on Literature and Art" (Bashu Publishing House, 2008) and Raymond Williams' "Marxism and Literature" (trans. Wang Ebo, Henan University Press, 2008).

The $8^{\text {th }}$ annual meeting of China and Oversea Literary Theory Society entitled "International Marxist Literary Theory Construction" was held in Chengdu. Soon afterward, "Research on Twentieth Century Marxist Literary Theory in Different Countries (vol 1-7)" (ed. Cheng Zhengmin \& Tong Qingbing) was published by Peking University Press in 2011. In short, China's translation of West Marxism has been intermingling with academic researches all the way and it has become a very important reference and theoretic resource for China's building of Marxist literary theory with Chinese characteristics in the new century.

\section{Conclusions}

The modernization of China's literary theories should have been a slow and complex process, but it was accelerated by the great impact from translation ad introduction of Western contemporary literary theories from early $19^{\text {th }}$ century. The concepts, paradigms and categories imported from the West undermined the discoursing patterns and specialized terminology of Chinese traditional literary theories. Cao Shunqing once identified this danger caused by indiscriminate application of Western contemporary theories and abandon of the essence of Chinese classic literary theories as "aphasia" of Chinese literary theories and a cultural anomaly, which generated wide discussion on this issue in Chinese academia. [24] However, some scholars held that translation of Western contemporary literary theories factually aided the modernization of Chinese ancient literary theories. "The modernization of Chinese ancient literary theories should firstly be attributed to translation, because it directly inputs new academic recourses and 
patterns which provide China with first-handed and ready-made patterns and intellectual models." [25]To get out of the dilemma of these two contradictory attitudes towards Western contemporary literary theories, retrospection and summarization of the process of translation of Western contemporary theories in China is essential and necessary. This research on the process is helpful to recognize the meaning and significance of Western contemporary literary theories between Sino-Western cultural communication and exchange, and what's more, the research on the power manipulating the translation activities is beneficial for us to rationally reconsider the feasible ways and directions to construct China's literary theories in the present new era, because it not only keeps us off the provincially conservative "self-dependence" and "self-respect" caused by "cultural nationalism" but also helps us look through the fake elimination of the contradiction between "universalism" and "unconventionality" in the present aggressive context of "cultural commonness" caused by globalization and Cosmopolitanism.

\section{Acknowledgements}

This essay is an achievement of the project "Case Study of Local Literature's Canonization in Network Environment from the SWOT Analysis" (网络环境下本土文学经典化案 例 SWOT 分析) (WLWH17-41) supported by chief research base of Sichuan Provincial Department of education: network culture research center. I am grateful to the fund to enable me to make research for this project.

\section{REFERENCES}

[1] R.Osbourne: "Freud and Marx". trans.Dong Siqiu, Beijing: Joint Publishing Press, 1986,P192.

[2] Yuan Kejia: “'Literature of Human' and 'Literature of People"”, Tianjin: "Yi Shi Bao", Nov., 7 $7^{\text {th }}, 1947$.

[3] Chen Houcheng, Wang Ning: "Western contemporary literary Criticism in China", Tianjin: Baihua Literature and ArtPublishing House, 2000, P113.

[4] Zhang Xianglong, Du Xiaozhen, Huang Yingquan: "phenomenological trend in China", Beijing: Capital Normal University Press, 2001, P60.

[5] Heidegger: "A Thing Facing up with Thought", Trans Chen Xiaowen, Sun Zhouing, Beijing: the Commercial Press, 1996, P84.

[6] Zhao Yiheng: "The New Criticism in New China", Journal of Zhejiang University (Humanities and Social Sciences) 2012(1), P139.

[7] Liao Qiyi: "The contemporary Western translation theories", Nanjing: Yilin Press, 2000, P64-65.
[8] Zhou Xian: "The Tension of Modernity", "Series of Book on Construction of Literature and Art in New Era·Foreword". edited. Qian Zhongwen \&Tong Qingbin, Beijing: Capital Normal University Press, 2001, P1.

[9] Li Jing: "Investigation on Contemporary Translation in China (1966-1976)", Tianjin: Nan Kai University Press, 2008, P46.

[10] Yuan Kejia: "Thomas Stearns Eliot: A Stubborn literati Employed by American and British Imperialists", "Wenxue Pinglun" (Literature Criticism), 1960(6), P14-29.

[11] René Wellek: "Principles of Literary Criticism", trans. Shi Fu, "Xiandai Waiguo Zhexue Shehui Kexue Wenzhai (Digect of Foreign Social Sciences)", 1964(1), P9-13.

[12] Chen Jianhua, Geng Haiying: "30 Years: Russian Formalist Literary Theory in China", "Xuexi yu Tansuo" (Study \& Exploration), 2009(5), P197.

[13] Zhao Yiheng: "The New Criticism in New China", Journal of Zhejiang University (Humanities and Social Sciences) 2012(1), P139.

[14] Zhu Liyuan: “A Survey on Development of Literary Theory and Criticism in New Era", Shenyang, Chunfeng Literature and Art Publishing House, 2006.

[15] Zhang Canhui: "Heiddeger's Philosophy in China", "China's Phenomenology and Philosophy Criticism"No.4, Shanghai: Shanghai Translation Pressing House, P335.

[16] Liao Simei: "Translation and dissemination of structuralism in China", "Xueshu Lilun Yu Tansuo"( Academic theory and exploration),2007(8).

[17] Chen Taisheng: "Structuralism Criticism in China", "Shehui Kexue Yanjiu” (Social Science Research), 1999(4), P125.

[18] Zhang Hui: "The Fate of China's Translation of 'the New Criticism' in the New Era", "Xueshu Luntan" (Academic Forum) 2011(1), P152.

[19] Li Qingqing, Yuan Jing: “The Meaning of 'Form'Introspection of Resent Years' Formalism Literary Theories in Chinese Academia", "Zhongguo Wenxue Yanjiu”(Research Of Chinese Literature),2013(2), P6-7.

[20] Feng Zongxin: "Introduction of structuralism and China's Native Literary Criticism Theories", "Wenxue Lilun Qianyan (Frontiers of Literary Theory)", 2014(2), P73.

[21] Chen Houcheng, Wang Ning: "Western Contemporary Literary Criticism in China", Tianjin: Baihua Literature and Art Publishing House, 2000, P1.

[22] Chen Xiaoming: "Structuralism and Post-structuralism in Chia”, Beijing: Capital Normal University Press, 2002, P1.

[23] Wang Wei: "From Translation to Local Construction-The Prevalence of Reception Aesthetics in Mainland", Journal of Jishou University (Social Science Edition), 2012(3), P33.

[24] Cao Shunqing: "Aphasia of Literary Theory and Cultural Anomaly", "Wenyi Zhengming (Creation and Contention)"1996(2), P 50-58.

[25] Fu Ying: "Translation of Foreign Literary Theories and its Influences on Chinese Version of Literary Principles and Criticism_-Reviewing on literary Principle and Criticism by Kuohoruna", Journal of Jinan University (Philosophy \& Science Edition), 2011(11), P84. 